\title{
Synergy of novel coumarin derivatives and tamoxifen in blocking growth and inducing apoptosis of breast cancer cells
}

\author{
Lulzime Ballazhi ${ }^{1,2}$, Faik Imeri ${ }^{3}$, Aleksandar Dimovski ${ }^{1}$, Ahmed Jashari ${ }^{4}$, \\ Emil Popovski ${ }^{5}$, Pranvera Breznica-Selmani ${ }^{1,6}$, Bozhana Mikhova ${ }^{7}$, Gerald Dräger ${ }^{8}$, \\ Edita Alili-Idrizi², Kristina Mladenovska ${ }^{1 *}$ \\ ${ }^{1}$ Faculty of Pharmacy, University "Ss Cyril and Methodius", Mother Theresa 47, 1000 Skopje, Macedonia \\ ${ }^{2}$ Faculty of Medical Science, State University of Tetovo, Pashe Deralla bb, 1200 Tetovo, Macedonia \\ ${ }^{3}$ Institute of Pharmacology, University of Bern, Friedbühlstrasse 49, CH-3010 Bern, Switzerland \\ ${ }^{4}$ Faculty of Natural Sciences \& Mathematics, State University of Tetovo, Pashe Deralla bb, 1200 Tetovo, Macedonia \\ Institute of Chemistry, Faculty of Natural Sciences \& Mathematics, University "Ss. Cyril and Methodius", \\ PO Box 162, 1000 Skopje, Macedonia \\ ${ }^{6}$ Faculty of Medicine, University "Hasan Pristina", Mother Theresa 10 000, Pristina, Kosovo \\ ${ }^{7}$ Institute of Organic Chemistry with Centre of Phytochemistry, Bulgarian Academy of Sciences, \\ Acad. G. Bonchev 9, 1113 Sofia, Bulgaria \\ ${ }^{8}$ Institute of Organic Chemistry, Leibniz Universität Hannover, D-30167, Hannover, Germany
}

Received: October 2014; Accepted: November 2014

\begin{abstract}
Possible synergistic effect of tamoxifen $(2 \mu \mathrm{M})$ and hydrazinyldiene-chroman-2,4-diones $(10-100 \mu \mathrm{M})$ was examined with an aim to create more effective treatment for ER+ breast cancer. Anti-breast cancer effect has been evaluated on the proliferation of MCF-7 breast adenocarcinoma cells using MTT and alamarBlue assays. Cell viability was evaluated after $48 \mathrm{~h}$-treatment and the $I C s_{50}$ of the coumarin derivatives were determined. The apoptotic effect was evaluated by detection of PARP cleavage and reduced activity of the survival kinase Akt.

The results demonstrated dose-dependent activity, with a percent of growth inhibition after combination treatment being significantly higher $(53 \%$ to $79 \%, 10 \mu \mathrm{M}$ and $100 \mu \mathrm{M}$, respectively) than the one in the cell lines treated with tamoxifen (29\% to $37 \%)$ and the synthesized coumarin derivatives alone ( $11 \%$ to $68 \%, 10 \mu \mathrm{M}$ and $100 \mu \mathrm{M}$, respectively). The $I C s_{50}$ of the synthesized compounds significantly decreased in synergy with tamoxifen (33\% to 51\%). Coumarin derivative having thiazole moiety with additional methyl groups attached to the carbons at positions 5 and 4 in the thiazole ring showed to be the most potent, with $I C_{50} 20 \mu \mathrm{M}$ when administered alone and $10 \mu \mathrm{M}$ in synergy with tamoxifen. The levels of phospho- $\mathrm{Thr}^{308}$ Akt were down-regulated by the combination treatment, pointing to tyrosine kinase phosphorylation inhibition. In conclusion, the novel coumarin derivatives enhance the activity of tamoxifen and this combination may be suitable for prevention of ER+ breast cancer or development of related compounds. Further studies are needed to elucidate precisely the type of receptor involved in the activity and the mechanism of action.
\end{abstract}

Keywords: hydrazinyldiene-chroman-2,4-diones, tamoxifen, breast cancer, MCF-7 cells, antiproliferative effect

* tel: 0038923126032 ; fax: 0038923123054

e-mail:krml@ff.ukim.edu.mk 


\section{Introduction}

The balance between proliferation and cell death, mainly apoptosis, is crucial in determining the overall growth and regression of tumor. For this reason, traditional cytotoxic agents, such as DNA intercalating agents, DNA cross-linking agents, topoisomerase inhibitors, cytoskeleton disrupting agents and antimetabolites have usually been targeted to damage the aberrantly dividing cancer cells by interrupting the cell division process (Hengartner, 2000; Johnstone et al., 2002; Mehlen and Puisieux, 2006). However, rapidly growing nonmalignant cells are also significantly affected, which in turn, limits efficacy and probably increases the risk of drug resistance, particularly when toxicities lead to less than optimal drug dosing. Drug resistance, the signal transductions within the process of oncogenesis, cancer cell survival and metastasis are complex, and for survival, cancer cells often rely on redundant signaling pathways when the original pathway is blocked. Therefore, to achieve the best outcome for the cancer patients, often several anti-cancer agents that inhibit multiple targets or redundant pathways are combined in the treatment regimen (Li et al., 2014; LoRusso et al., 2012). Treatment combinations, including combination of nonspecific small molecule chemotherapeutic agents have been successfully applied to various cancer types, including (metastatic) breast cancer (Lee and Nan, 2012).

Breast cancer is still the most frequent malignancy cancer in women and principal cause of cancer death for females worldwide (Jemal et al., 2009; Ferlay et al., 2010). It is estimated that app. $80 \%$ of the breast tumors are estrogen receptor positive (ER+) and their growth is stimulated by estrogens (Hertz et al., 2009). Despite tremendous progress in their treatment during past decades, severe toxic side-effects and de novo and acquired resistance to the existing therapies present a major clinical problem urging for design and development of novel drugs and treatment combinations.

The coumarin (benzopyran-2-one) ring system, present in natural products, has intrigued medicinal chemists for decades to explore the natural coumarins or their synthetic analogs for their applicability as anticancer drugs due to the antiproliferative and cytotoxic effect on malignant cells and usefulness in prevention of recurrence and metastases of malignant cells (Sadiu et al., 2012; Goel et al., 2009; Jacquot et al., 2001). Of particular interest in breast cancer chemotherapy, some coumarins and their active metabolite 7-hydroxycoumarin analogs have shown sulfatase and aromatase inhibitory activities. Coumarin based selective estrogen receptor modulators and coumarin-estrogen conjugates have also been described as potential anti-breast cancer agents (Musa et al., 2008).

In search for novel coumarin based antibreast cancer drugs, we have synthesized compounds that combine the coumarin core and five membered heterocycles (isoxazoles and thiazoles) in hydrazinylidiene-chroman-2,4-di- ones (Jashari et al., 2013; 2014; Ballazhi et al., accepted for publication). Izoxazole and thiazole substituents were chosen as important pharmacophores in agents with antiproliferative and tumor vascular-disrupting activity (Gulsory and Guzeldemirci, 2007; Poma et al., 2007). Eight compounds were synthesized, showing to have antiproliferative effects and induce apoptosis on breast cancer cells MCF7 and MDA-MB-231 (Jashari et al., 2014) and bone and lung metastatic cell lines from breast cancer, SCP1833 and SCP4175, respectively (Ballazhi et al., accepted for publication). Three of the eight compounds tested, having thiazole moiety, without or with additional methyl group(s) attached to the carbon(s) at the position(s) 5 and/or 4 in the thiazole ring showed to be the most potent, requiring further evaluation.

Based on these findings, the aim of this study was to test their antiproliferative effects on MCF-7 cell lines in synergy with tamoxifen (Tam). Tam induces growth arrest and apoptosis in breast cancer cells through the inhibition of estrogen binding to the ERs, improving the clinical outcome of patients with both early and advanced breast cancer. Also, at high concentrations $(\geq 10 \mu \mathrm{M})$, it has been shown to mediate apoptosis in ER-negative cancer cells (Higgins et al., 2011; Fisher et al., 2005; Gelmann, 1996; Sutherland et al., 1982). However, about half of patients with advanced ER+ disease immediately fail to respond to Tam, and the disease progresses to a resistant phenotype. Mechanisms by which breast cancer cells become resistant may include changes in the expression of ER $\alpha$ or ER $\beta$, alterations in co-regulatory proteins, and the influences of cellular kinase signal transduction pathways (Kruh, 2003; Dorsses et al., 2001). Significantly higher concentration-dependent reduction in cell viability and increase in apoptosis, confirmed by PARP cleavage and reduced activity of the survival kinase Akt, was observed with combination of Tam and coumarin derivatives in comparison with the compounds alone.

\section{Materials and Methods}

\section{Cell culturing}

The human breast cancer cell line MCF-7 (MCF-7 from American Type Culture Collection) was maintained in Dulbecco's modified eagle's medium (DMEM, Invitrogen, Switzerland) containing $10 \%$ fetal bovine serum (FBS, Invitrogen, Switzerland) supplemented with $300 \mu \mathrm{g} \mathrm{mL}^{-1}$ glu-

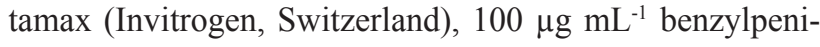
cillin (Invitrogen, Switzerland) and 100 units $\mathrm{mL}^{-}$streptomycin (Invitrogen, Switzerland). MCF-7 cells were incubated at $37^{\circ} \mathrm{C}$ in an atmosphere containing $5 \% \mathrm{CO}_{2}$. For experiments, cells from exponentially growing culture were used.

\section{MTT assay}

Cytotoxic effects of Tam (T5648 Sigma, USA), 4-hydroxycoumarin (4-HC, as a reference, Merck KGaA, Ger- 


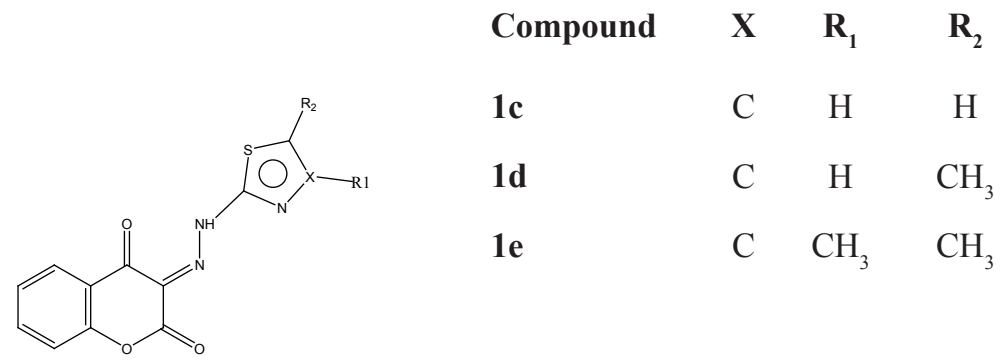

Fig. 1. Structure of the novel hydrazinylidiene-chroman-2,4-diones obtained after reaction of the coumarin with the corrsponding salts of the heterocyclic amines (Jashari et al., 2013; 2014; Ballazhi et al., accepted for publication).

many) and the three coumarin derivatives synthesized in our laboratory (1c, 1d, 1e; Fig. 1) on MCF-7 cells were determined by $3[4,5$-dimethylthiazol-2-yl]-2, 5-diphenyltetrazolium bromide (MTT, Sigma-Aldrich, USA) assay.

In short, $100 \mu \mathrm{L}$ of the growth medium DMEM was poured in each well of a 96-well plate and seeded with $5000 \mathrm{MCF}-7$ cells per well. Cells were allowed to attach overnight and then $4-\mathrm{HC}, 1 \mathrm{c}, 1 \mathrm{~d}$ and $1 \mathrm{e}$ in increasing concentrations $(10,20,50,100 \mu \mathrm{M})$ and Tam $(2 \mu \mathrm{M})$ were added to respective wells. After 48 hours of incubation at 37 ${ }^{\circ} \mathrm{C}, 5 \% \mathrm{CO}_{2}$ and relative humidity $95 \%, 20 \mu \mathrm{L}$ of MTT reagent $\left(5 \mathrm{mg} \mathrm{mL}^{-1}\right)$ was added to each well. After additional incubation within 4 hours, $100 \mu \mathrm{L}$ of MTT-solvent ( $4 \mathrm{mM}$ $\mathrm{HCl}, 0.1 \%$ Nonidet P-40 (in isopropanol), AppliChem, Germany) was added to each well to solubilize the MTT crystals. The plates were covered with tinfoil and the cells were agitated on orbital shaker for $15 \mathrm{~min}$. Then, the absorbance was read at $570 \mathrm{~nm}$ in a microplate reader (SpectraMax M2 Fluorimeter, BucherBiotec Inc, USA). All experiments were performed at least 3 times, with 4 wells for each concentration of the tested agents. The control cells were grown under the same conditions without adding the test compounds. Cell survival was calculated using the following formula:

$\%$ of cell viability $=\frac{\text { mean experimental absorbance }}{\text { mean control absorbance }} \cdot 100 \%$

\section{AlamarBlue assay}

AlamarBlue assay was performed in 96-well microtiter plates. In each well, $100 \mu \mathrm{L}$ of the culture medium with 4000 cells was added. After 24 hours, the medium was removed from all wells and replaced by fresh medium (150 $\mu \mathrm{L})$ containing the compounds. After 48 hours of incubation, the plates were inspected under an inverted microscope to assure growth of the controls and sterile conditions. Afterwards, alamarBlue reagent ${ }^{\circledR}(10 \mu \mathrm{L})$ (Invitrogen, Basel, Switzerland) was added to each well and the plates were incubated for another 2 to 3 hours. Then, the plates were read with a SpectraMax microplate reader (SpectraMax M2 Fluorimeter, BucherBiotec Inc, USA) at excitation wavelength of $540 \mathrm{~nm}$ and emission wavelength of $570 \mathrm{~nm}$. The percent of viability was expressed as fluorescence counts in the presence of test compound as a percentage of that in the vehicle control.

\section{Western blot analysis}

The procedure for Western blot analysis has been already described (Doll et al., 2005; Jashari et al., 2014). Stimulated cells were homogenized in lysis buffer and centrifuged for 10 minutes at $14000 \times \mathrm{g}$. The supernatant was taken for protein determination. $30 \mu \mathrm{g}$ of protein were separated on SDS-PAGE, transferred to nitrocellulose membrane and Western blot analysis was performed using antibodies as indicated in the figure legend (Figure 3).

\section{Statistical analysis}

The $50 \%$ inhibitory concentration $\left(I C_{50}\right)$ was determined as the anticancer drug concentration causing $50 \%$ reduction in cell viability and calculated from the viability curves by linear interpolation between the values immediately above and below the 50\% inhibition using the Bliss's software (Bliss Co, Castro Valley, CA 94552, USA).

The results were presented as mean $\pm \mathrm{SD}$ and the statistical analysis was performed using one-way analysis of variance (ANOVA) followed by a Bonferroni's post hoc test for multiple comparisons (GraphPad InStat version 3.00 for Windows NT, GraphPad Software, San Diego, CA, USA).

\section{Results}

Cytotoxic and anti-proliferative effects of Tam, 4-HC and coumarin derivatives on breast cancer cells

The effects of Tam, 4-HC and coumarin derivatives (1c, $1 \mathrm{~d}$ and $1 \mathrm{e}$ ) on cell viability and proliferation, alone or in combination, evaluated by MTT and alamarBlue assays, are presented in Fig. 2A and 2B, respectively. Differences in cell viability and proliferation were observed when data obtained from the two assays were compared, with the per-

Макед. фарм. билт., 60 (1) 35 - 44 (2014) 

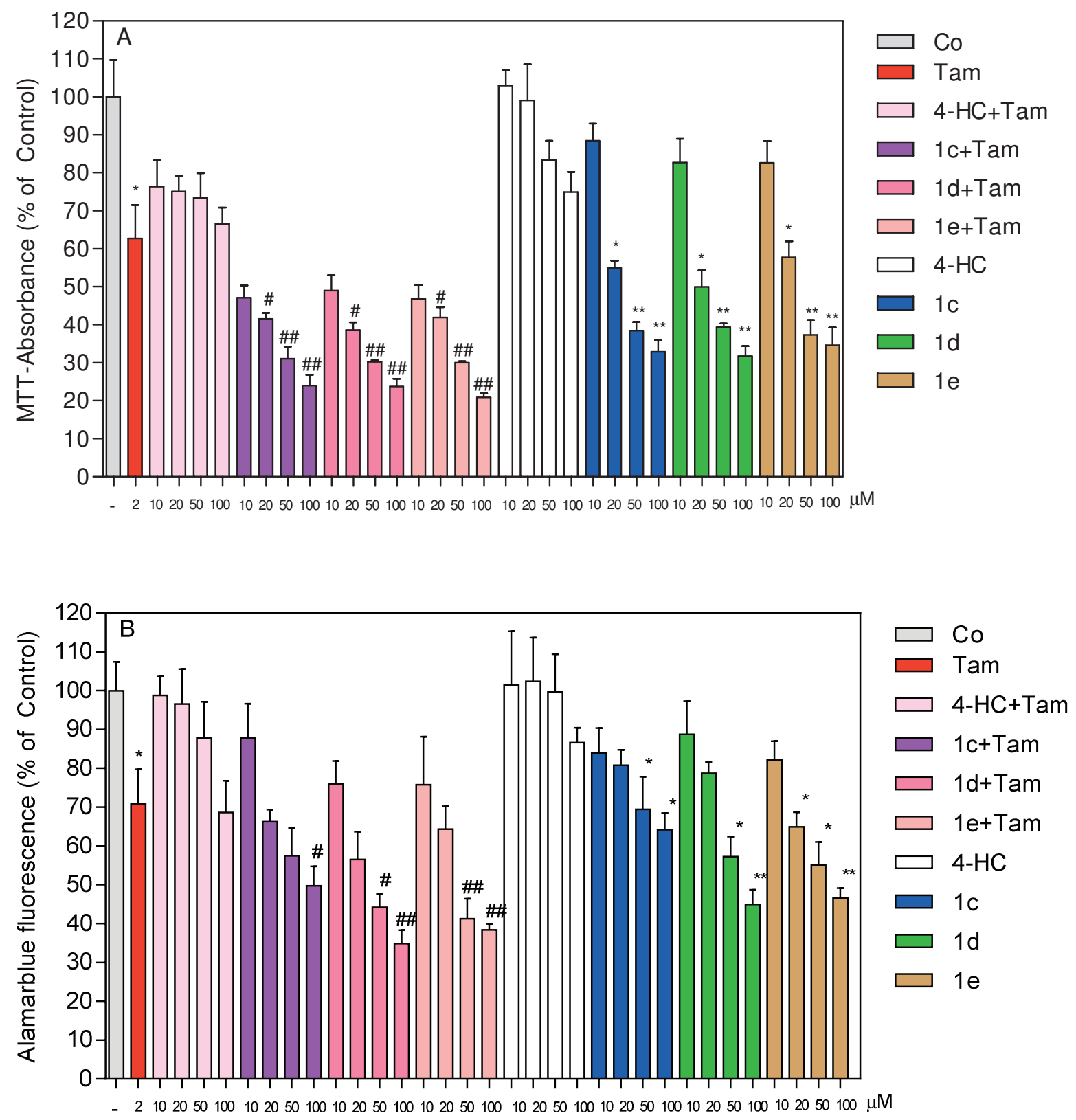

Fig 2. Effects of Tam, 4-HC and coumarin derivatives, alone or in combination, on viability of MCF-7 breast cancer cells, measured by MTT (A) and alamarBlue (B) assays. The percentage of viable cells was determined as a ratio of treated cells to untreated controls. Results are expressed as mean \pm SEM of triplicate experiments. ${ }^{*} p<0.05$ considered statistically significant when compared to the unstimulated control values; ${ }^{*} \mathrm{p}<0.05,{ }^{\#} \mathrm{p}<0.01$ considered statistically significant when compared to the Tam-stimulated values.

cent of growth inhibition being higher when MTT assay was applied.

The results showed that only synthesized coumarin derivatives, but not 4-HC induced anti-proliferative effect in MCF-7 cell lines. Even when 4-HC was administered with Tam, the number of viable cells remained high, from app. $67 \%$ (100 $\mu \mathrm{M}$, MTT assay) to $100 \%(10 \mu \mathrm{M}$, alamarBlue assay). 4-HC alone induced no apoptosis when concentrations equal to or lower than $20 \mu \mathrm{M}$ were applied.

The percentage of growth inhibition after treatment with the corresponding hydrazinylidiene-chroman-2,4-diones was dramatically higher than the one in the untreated control cells, especially when concentrations higher than $10 \mu \mathrm{M}$ were applied in synergy with Tam. Namely, 
as MTT and alamarBlue assays showed, when the synthesized agents were administered in combination with Tam, the percent of growth inhibition ranged from app. 51\% to app. 79\% (MTT assay) and from app. 12\% to 65\% (alamarBlue assay), with increase in the concentration of the agents from 10 to $100 \mu \mathrm{M}$. Administration of Tam alone decreased the number of viable cells to lower extent, from $37 \%$ (MTT assay) to 29\% (alamarBlue assay), expressed as a percent from control (100\%). Similarly, when synthesized compounds were administered alone, with the lowest concentration, the percent of viable cells was higher in comparison with Tam alone, from $89 \%$ to $83 \%$ (MTT and alamarBlue assays) vs. app. 63\% (MTT assay) and 71\% (alamarBlue assay) for Tam, respectively. With increase in the concentration of the synthesized coumarin derivatives, from 50 to $100 \mu \mathrm{M}$, when they solely administered, the percent of viable cells was lower than the one when only Tam was administered, app. 32\% and 45\% (1d, $100 \mu \mathrm{M}$, MTT and alamarBlue assay, respectively). Synergy of the syn- thesized agents with Tam resulted in average $30.3 \pm 7.6 \%$ (MTT assay) to $21.0 \pm 3.5 \%$ (alamarBlue assay) higher decrease in viable cells in comparison with the coumarin derivatives alone, when administered in concentration of $100 \mu \mathrm{M}$. When concentration of $10 \mu \mathrm{M}$ was applied, decrease in non-apoptotic cells was $43.3 \pm 2.5 \%$ (MTT assay) to $11.1 \pm 4.7 \%$ higher in comparison with the coumarin derivatives alone.

As Table 1 shows, the $I C_{50}$ of the synthesized compounds significantly decreased when they administered in synergy with Tam, from $33 \%$ (1c, alamarBlue assay) to $51 \%$ (1c, MTT assay). The coumarin derivative having thiazole moiety, with additional methyl groups attached to the carbons at the positions 5 and 4 in the thiazole ring (1e) showed to be the most potent, with $I C_{50}$ around $20 \mu \mathrm{M}$ and $10 \mu \mathrm{M}$ when administered alone and in synergy with Tam, respectively (Table 1).

Table 1. Cytotoxicity of 4-hydroxycoumarin and its synthesized derivatives against MCF-7 breast cancer cell lines determined by MTT and alamarBlue assays ${ }^{\mathrm{a}}$

\begin{tabular}{|c|c|c|c|c|}
\hline \multirow{2}{*}{$\begin{array}{l}\text { Coumarin } \\
\text { derivatives }\end{array}$} & \multicolumn{2}{|c|}{$\begin{array}{l}l C_{50}(\mu \mathrm{M}) \\
\text { MTT assay }\end{array}$} & \multicolumn{2}{|c|}{$\begin{array}{c}C_{50}(\mu \mathrm{M}) \\
\text { AlamarBlue assay }\end{array}$} \\
\hline & Compound & Compound+Tam $(2 \mu \mathrm{M})$ & Compound & Compound+Tam $(2 \mu \mathrm{M})$ \\
\hline 4-HC & $>100$ & $>100$ & $>100$ & $>100$ \\
\hline $1 \mathrm{c}$ & $19.76 \pm 3.95$ & $9.72 \pm 3.91$ & $29.60 \pm 2.19$ & $19.76 \pm 5.52$ \\
\hline $1 d$ & $19.64 \pm 5.40$ & $10.05 \pm 4.58$ & $29.24 \pm 1.60$ & $16.60 \pm 7.87$ \\
\hline $1 \mathrm{e}$ & $19.94 \pm 1.90$ & $9.80 \pm 3.45$ & $19.91 \pm 5.98$ & $10.33 \pm 2.00$ \\
\hline
\end{tabular}

${ }^{a}$ Values are means \pm SD from at least three independent experiments

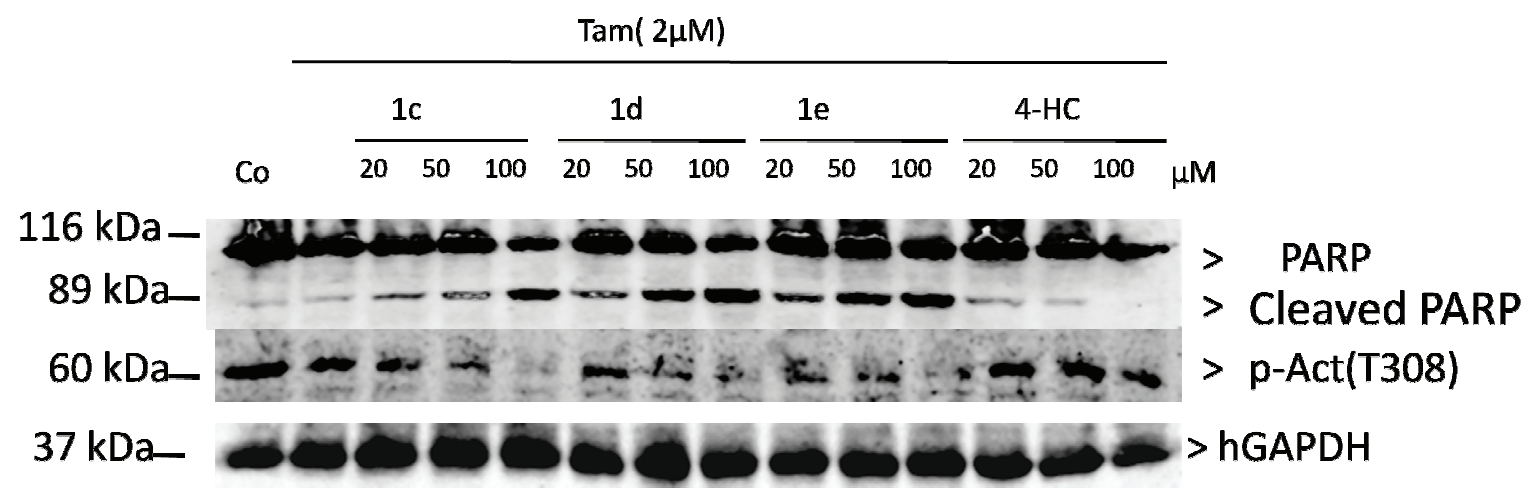

Fig. 3. Western blot analysis of cleaved PARP and phospho-Akt after incubation of MCF-7 cells with the vehicle (Co), Tam and Tam+novel coumarin derivatives for $48 \mathrm{~h}$. Western blot analysis was performed by using antibodies against PARP (upper panels), phospho-Thr308-Akt (middle panels) and the house-keeping protein GAPDH (lower panels). The data represent three identical experiments. 
Apoptotic effects of Tam and coumarin derivatives on breast cancer cells

We investigated whether the combination of Tam and 4-HC or coumarin derivatives synergistically affected apoptosis of MCF-7 cells. PARP (poly ADP ribose polymerase) cleavage which is a marker of apoptosis was determined by Western blot analysis. Fig. 3 shows that in MCF7 cells, all concentrations of $1 \mathrm{c}, 1 \mathrm{~d}$ and $1 \mathrm{e}$ in combination with Tam led to a reduced protein expression of $116 \mathrm{kDa}$ full length PARP with a concentration-dependent appearance of a cleavage product at $86 \mathrm{kDa}$. In parallel, the levels of phospho- $\mathrm{Thr}^{308}$ Akt were downregulated by combination of Tam and 1c, 1d and 1e when compared to control and to combination of Tam and 4-HC treated cells. Akt is a well known protein kinase involved in cell growth and survival and reduced activity often correlates with reduced proliferation and increased apoptosis. The level of phospho-Thr ${ }^{308}$ Akt is well accepted to reflect Akt activity.

\section{Discussion}

Tam, a selective ER modulator is a partial agonist of ER, blocking the proliferative effects of estrogen via this receptor. Since its introduction in cancer therapy, it has become the standard treatment option for hormone-responsive breast cancer patients (Bush, 2007; Goldhirsch et al., 2009; Fisher et al., 1998; 2005). It was shown that the Tam effect can be reversed by addition of $17 \beta$-estradiol and that Tam has no effect on the cell cycle kinetics of the receptor-negative MDA-MB-231 cells, confirming that the antiestrogen effect is mediated through the ER (Osborne et al., 1982). This was also confirmed in the study of Gelmann (1996) and Mandlekar and Kong (2001), in which more apoptosis was induced in ER+ MCF-7 breast cancer cells compared to the MDA-MB-231 cells. Several hormone receptor-independent effects have been also described for Tam, leading to apoptosis when higher concentrations are applied (Fisher and Redmond, 1992; Mandlekar and Kong, 2001).

Despite the relative safety and significant anti-neoplastic activities of Tam, most initially responsive breast tumors develop resistance to this drug. Even though an improved understanding, resistance to anti-estrogen therapy remains a significant clinical problem. However, combination therapies of Tam with other drugs that aimed at the signaling pathways underlying the development of resistance may be a potential mean of delaying the arrival resistance.

One of the new treatment strategies for improving clinical outcome in breast cancer involves development of ER antagonists (Musa et al., 2008). Estrogens are formed exclusively in peripheral tissues, and there are two pathways associated with their synthesis in such tissues, the aromatase and sulfatase pathways. The aromatase pathway involves the conversion of androgen precursor, androstenedione, to estrone by the aromatase (AR) enzyme complex, while the estrone sulfatase pathways (E1-STS) involves the conversion of estrone formed via the aromatase route to estrone sulfate (E1S) by the sulfotransferase enzymes (Woo et al., 1998; Suzuki et al., 2003; Yoshimura et al., 2004; Utsumi et al., 1999; Miyoshi et al., 2003). The E1STS pathway is considered the major source leading to estrogen formation, causing low response rate in ER+ breast tumor patients to highly potent AR inhibitor (Jonat et al., 1996; Santner et al., 1984; Yamamoto et al., 1993). Furthermore, studies have shown that endocrine therapy involving the inhibition of enzymes within the steroid biosynthetic cascade may be one route to controlling the disease. This approach has led to the development of novel coumarins as STS (Purohit et al., 2003) as well as AR inhibitors (Chen et al., 2004).

Considering all above mentioned, $\mathrm{MCF}-7$ breast cancer cell were used to evaluate the synergy effect of Tam and the coumarin derivatives synthesized in our laboratory. MCF7 cells were used because they possess several ideal characteristics particular to the mammary epithelium. These include the ability for MCF-7 cells to process estrogen, in the form of estradiol, via ER in the cell cytoplasm, which in turn regulates the cell proliferation and survival and the down-regulation of genes with anti-proliferative or proapoptotic activity (Huwiler et al., 1995). This makes the MCF-7 cell line an ER+ control cell line. In addition, treatment of MCF-7 cancer cells with anti-estrogens can modulate insulin-like growth factor finding proteins, which ultimately have the effect of a reduction in cell growth (Levenson and Jordan, 1997). It was also demonstrated that Tam, at pharmacological concentrations achievable in tumor tissue of Tam-treated breast cancer patients, can induce rapid death of MCF-7 cells associated with release of mitochondrial cytochrome $\mathrm{c}$, a decrease of mitochondrial membrane potential and an increase in production of reactive oxygen species (Kallio et al., 2005). This suggests that disruption of mitochondrial function but not immediate activation of caspase-9 or cleavage of poly (ADP-ribose) polymerase has a primary role in the acute death response of the MCF-7 cells. Accordingly, an inhibitor of mitochondrial permeability transition but not the caspase inhibitor could be able to protect MCF-7 cells against Tam.

In this study, we have demonstrated that the antiestrogen Tam, used in concentration of $2 \mu \mathrm{M}$ inhibits proliferation of ER+ MCF-7 cells. These results, are similar to those reported by Lippman et al. (1976) and Sutherland et al. (1982) who found that, at concentrations of Tam observed in women treated for breast cancer $(<1.0 \mu \mathrm{M})$, the antiestrogen slowed proliferation but was not lethal to MCF-7 cells in short-term culture. Literature data suggest that Tam inhibits cell proliferation by invoking a transition delay in early to mid- $\mathrm{G}_{1}$ phase of the cell cycle (Osborne et al., 1983).

In our previous studies, we have shown that three of the eight newly synthesized coumarin derivatives, having thiazole moiety without or with additional methyl group(s) 
attached to the carbon(s) at the position(s) 5 and/or 4 in the thiazole ring were effective in inhibiting the growth of different cancer cells, including MCF-7 breast cancer cells, in a dose- and time-dependent manner (Jashari et al., 2014). Similar results were obtained when estrogenic activity on MCF-7 breast carcinoma cells of compounds prepared by addition of 2-aminothiophenol to substituted 4-HC derivatives was evaluated. Among the compounds tested, 6,12-dihydro-3-methoxy-1-benzopyrano[3,4-b] [1,4]benzothiazin-6-one and 6,12-dihydro-3-hydroxy1-benzpyrano[3,4-b][1,4]benzothiazin-6-one exhibited an ER-dependent proliferation and a high binding affinity to ER, but a moderate capacity to activate the transcription of a reporter gene (Jacquot et al., 2001). The pyrone-substituted coumarin, namely warfarin, isoflavone genistein and 6,7-dihydroxycoumarin known as esculetin were also examined, under similar assay procedures, using the MCF-7 cell lines. Proliferation assays yielded that the MCF-7 cells tested were quite sensitive to the effects of all three compounds, with potency of growth inhibition by genistein being greater than the one of esculetin which, in turn was greater than that of warfarin. Genistein has exceptionally interesting, multidirectional therapeutic properties and the biological activity of this substance, as of all isoflavones, is conditioned by the location of the phenyl ring near the third carbon of the benzo- $\gamma$-pyrone. It has been shown that inhibition of cancer cell proliferation was attributed to inhibition of several key enzymes, especially tyrosine kinase, which plays a critical role in cell proliferation and transformation, and is also associated with oncogene expression in breast cancer. The investigation of how esculetin, genistein and warfarin affect the signal transduction cascade and cell cycle progression in MCF-7 cells confirmed inhibition of tyrosine phosphorylation, with warfarin being a less potent inhibitor of cell proliferation and metabolic activity than esculetin and genistein, partly due to the fact that it shows no significant tyrosine kinase phosphorylation inhibition in comparison to the other compounds (Lacy and O'Kenendy, 2004). In addition, in vitro studies showed that genistein also exhibited a synergistic additive effect when cancer cells were exposed to a combination treatment with Tam, confirming to have both estrogenic and anti-estrogenic effects (Tanos et al., 2002; Luczkiewicz et al., 2003).

All these findings implicated that the effects of Tam may be enhanced in combination with our coumarin derivatives, which was confirmed by a significant additive cytotoxic effect in the MCF-7 cell lines. Non-significant differences in cell viability and proliferation, observed when the data obtained from the two assays were compared, can be explained by the different sensitivity to the effects of the compounds on cellular metabolism of the two assays. The MTT assay is based on the reduction of tetrazolium salt such as MTT into formazan crystals by living cells, which determines mitochondrial activity. It relies on the activity of just one group of mitochondrial enzymes to predict adverse effects on metabolism, and in doing so may under- estimate metabolic effects, which was confirmed for interferons in the past (Jabbar et al., 1989). Upon entering the cells, the active ingredient of alamarBlue $\AA$, resazurin, is continuously reduced to resofurin which is further reduced to hydroresorufin. It is still unknown how this reduction occurs, intracellularly via enzyme activity or in the medium as a chemical reaction, although the reduced fluorescent form of alamarBlue was found in the cytoplasm of living and cells nucleus of dead cells (O'Brien et al., 2000). Our data are in contradiction with the previous study (Jabbar et al., 1989) and also with the results of Hamid et al. (2004) who reported slightly higher sensitivity for alamarBlue assay than the MTT assay for most of the tested drugs, out of 117 in total. However, it must be emphasizes that the results of Hamid et al. (2004) were obtained from tests in human hepatoma cell line HepG2, at a single point screen. When the drugs were re-tested in both assays for reconfirmation of cytotoxicity and determination of the $I C_{50}$ values, except for daunorubicin, the $I C_{50}$ values were comparable in both assays, pointing that both assays provide useful information to identify in vitro cytotoxic drugs at early stages of drug candidate selection. There is also possibility different results to be caused by different level of induction and/or inhibition of the metabolic enzymes responsible for transformation of cell toxicity end points, as was demonstrated using dicumarol (Hamid et al., 2004). This could be one of the reasons why combination treatment of Tam and 4-HC results in higher cell viability in comparison with Tam alone (Fig 2A and B). Namely, there are literature data that report on inhibition of microsomal mixed function oxidase by 4-HC (Deckert et al., 1972) and this could decrease Tam activity knowing that its antiestrogenic effect has been attributed to its metabolism to an active 4-hydroxy derivative and the avid binding of the active metabolite to the estrogen receptor. Biotransformation by $\mathrm{P} 450$ forms are expressed extrahepatically, in the breast and endometrium, and may be particularly important in determining tissue-specific effects of Tam (Crewe et al., 2002).

In addition, Tam has different partial agonist-antagonist activities in different tissues and the differences may be related in part to the milieu of ER coactivators and corepressors in these tissues. If a cell or tissue requires only activating factor 1 to interact with transcription factors at the promoter, Tam is agonistic. However, if a cell type requires activating factors 1 and 2 of the estrogen receptor to be functioning concurrently, Tam is antagonistic (Shou et al., 2004). There is a probability that the newly synthesized coumarine derivatives and 4-HC at higher concentrations $(50-100 \mu \mathrm{M})$ prevent activation of ER and co-actovators (such as A1B1) in MCF-7 cells, reduce the recruitment of co-activator complexes and enhance recruitment of corepressor complexes to Tam-bound Er on gene promoters, thus potentiating Tam's estrogen antagonist effects on gene expression and tumor growth. However, this should be confirmed in further studies in which MCF-7 breast can- 
cer cells, which express high levels of A1B1, will be treated with Tam alone and in combination with these coumarine derivatives. In addition, effects of these newly synthesized coumarine derivatives on mitochondrial permeability transition as well as enzyme induction/inhibition effects should be evaluated.

Our data demonstrated that Tam and 4-HC derivatives inhibited MCF-7cells proliferation by inducing apoptosis. The enhanced apoptosis may account for the synergistic inhibition of the combination treatment. The levels of phospho- $\mathrm{Thr}^{308}$ Akt were down-regulated by combination of Tam and the coumarin derivatives, pointing to tyrosine kinase phosphorylation inhibition.

\section{Conclusion}

The results of this study indicate that the combination of Tam and hydrazinyldiene-chroman-2,4-diones having thiazole moiety without or with additional methyl group(s) attached to the carbon(s) at the position(s) 5 and/or 4 in the thiazole ring can effectively inhibit cell proliferation and induce apoptotic pathway. They may be considered as new candidates that could contribute to the development of a large chemical library or related compounds by a combinatorial synthesis approach. Further studies are needed to elucidate with precision the type of receptor involved in the activity and their mechanism of action, including binding mode.

\section{References}

Ballazhi, L., Popovski, E., Jashari, A., Imeri, F., Ibrahimi, I., Mikhova, B., Mladenovska, K., Potential antiproliferative effect of novel isoxazolo- and thiazolo coumarin derivatives on bone and lung metatstases cells from breast cancer. Acta Pharm. accepted for publication.

Bush, N.J., 2007. Advances in hormonal therapy for breast cancer. Semin. Oncol. Nurs. 23, 46-54.

Chen, S., Cho, M., Karlsberg, K., Zhou, D., Yuan, Y.C., 2004. Biochemical and biological characterization of a novel antiaromatase coumarin derivative. J. Biol. Chem. 279, 48071-8.

Crewe, H.K., Notley, L.M., Wunsch, R.M., Lennard, M.S., Gillam, E.M., 2002. Metabolism of tamoxifen by recombinant human cytochrome P450 enzymes: formation of the 4-hydroxy, 4'-hydroxy and N-desmethyl metabolites and isomerization of trans-4-hydroxytamoxifen. Drug Metab Dispos. 30(8): 869-74.

Deckert, F.W., Remmer, H.K., 1972. In vitro inhibition of rat and human liver microsomal enzymes by 4-hydroxycoumarin anticoagulants and related compounds. Chemico-Biological Interactions, 5 (4): 255-263.

Doll, F., Pfeilschifter, J., Huwiler, A., 2005. The epidermal growth factor stimulates sphingosine kinase-1 expression and activity in the human mammary carcinoma cell line MCF7. Biochim. Biophys. Acta. 1738, 72-80.

Dorsses, L.C., Van der Filer, S., Brinkman, A., van Agthoven, T., Veldcholte, J., Berns, E.M., Klijn, J.G., Beex, L.V., Foekens, J.A., 2001. Tamoksifen resistance in breast cancer: elucidating mechanisms. Drugs 61, 1721-33.

Ferlay, J., Shin, H.R., Bray, F., Forman, D., Mathers, C., Parkin, D.M., 2010. Estimates of worldwide burden of cancer in 2008: GLOBOCAN 2008. Int. J. Cancer. 127, 2893-917.

Fischer, B., Redmond, C., 1992. Systemic therapy in nodenegative patients: updated findings from NSABP clinical trials. National surgical adjuvant breast and bowel project. J. Natl., Cancer Inst. Monogr. 11, 105-116.

Fisher, B., Costantino, J.P., Wickerham DL, Cecchini, R.S., Cronin, W.M., Robidoux, A., Bevers, T.B., Kavanah, M.T., Atkins, J.N., Margolese, R.G., Runowicz, C.D., James, J.M., Ford, L.G., Wolmark, N., 1998. Tamoxifen for prevention of breast cancer: report of the national surgical adjuvant breast and bowel project P-1 study. J. Natl. Cancer Inst. 90, 137188.

Fisher, B., Costantino, J.P., Wickerham, D.L., Cecchini, R.S., Cronin, W.M., Robidoux, A., Bevers, T.B., Kavanah, M.T., Atkins, J.N., Margolese, R.G., Runowicz, C.D., James, J.M., Ford, L.G., Wolmark, N., 2005. Tamoxifen for the prevention of breast cancer: current status of the national surgical adjuvant breast and bowel project P-1 study. J. Natl. Cancer Inst. 97, 1652-62.

Gelmann, E.P., 1996. Tamoxifen induction of apoptosis in estrogen receptor-negative cancers: new tricks for an old dog? J. Nat. Cancer Inst., 88, 224-26.

Goel, A., Prasad, A.K., Pramar, V.S., Ghosh, B., Saini, N., 2009. Apoptogenic effect of 7,8-diacetoxy-4-methylcoumarin and 7,8-diacetoxy-4-methylthio-coumarin in human lung adenocarcinoma cell line: Role of NF-B, Akt, ROS and MAP kinase pathway. Chem. Biol. Interact. 179, 363-74.

Goldhirsch, A., Ingle, J.N., Gelber, R.D., Coates, A.S., Thurlimann, B., Senn, H.J., 2009. Thresholds for therapies: highlights of the St Gallen International Expert Consendus on the primary therapy of early breast cancer. Ann. Oncol. 20, 1319-29.

Gulsory, E., Guzeldemirci, N.U., 2007. Synthesis and primary cytotoxicity evaluation of new imidazo [2,1-b] thiazole derivatives. Eur. J. Med. Chem. 42, 320-6.

Hamid, R., Rotshteyn, Y., Rabadi, L., Parikh, R., Bullock, P., 2004. Comparison of alamar blue and MTT assays for high through-put screening. Toxicol In Vitro. 18, 703-10.

Hengartner, M.O., 2000. The biochemistry of apoptosis. Nature 407, 770-6.

Hertz, D.L., McLeod, H.L., Hoskins, J.M., 2009. Pharmacogenetics of breast cancer therapies. Breast. 18, S59-S63.

Higgins, M.J., Baselga, J., 2011. Targeted therapies for breast cancer. J. Clin. Invest. 121, 3797-803.

Huwiler, A., Stabel, S., Fabbro, D., Pfeilschifter, J., 1995. Plateletderived growth factor and angiotensin II stimulate the mitogen-activated protein kinase cascade in renal mesangial cells: comparison of hypertrophic and hyperplastic agonists. Biochem J. 305, 777-84.

Jabbar, S.A.B., Twentyman, P.R., Watson, J.V., 1989. The MTT assay underestimates the growth inhibitory effects of interferons. Br. J. Cancer, 60, 523-528.

Jacquot, Y., Bermont, L., Giorgi, H., Refouvelet, B., Adessi, G.L., Daubrosse, E., Xicluna, A., 2001. Substituted benzopyranobenzothiazinones. Synthesis and estrogenic activity on MCF-7 breast carcinoma cells. Eur. J. Med. Chem. 36, 12736.

Jashari, A., Imeri, F., Ballazhi, L., Shabani, A., Mikhova, B., Dräger, G., Popovski, E., Huwiler, A., 2014. Synthesis and cellular characterization of novel isoxazolo- and 
thiazolohydrazinyldiene-chroman-2,4- diones on cancer and non-cancer cell growth and death. Bioorg. Med. Chem. 22, 2655-61.

Jashari, A., Popovski, E., Mikhova, B., Nikolova, R.P., Shivachev, B.L., 2013. 3-[2-(5-tert-Butyl-1,2-oxazol-3-yl) hydrazinylidene] chroman-2,4-dione, Acta Cryst. E69, o258.

Jemal, A., Siegel, R., Hao, Y., Xu, J., Thun, M.J., 2009. Cancer statistsics 2009. CA Cancer J. Clin. 59, 225-49.

Johnstone, R.W., Ruefli, A.A., Lowe, S.W., 2002. Apoptosis. A link between cancer genetics and chemotherapy. Cell 108, 153-64.

Jonat, W., Howell, A., Blomqvist, C., Eiermann, W., Winblad, G., Tyrrell, C., Mauriac, L., Roche, H., Lundgren, S., Hellmund, R., Azab, M., 1996. A randomised trial comparing two doses of the new selective aromatase inhibitor anastrozole (Arimidex) with megestrol acetate in postmenopausal patients with advanced breast cancer. Eur. J. Cancer. 32, 404-12.

Kallio, A., Zheng, A., Dahllund, J., Heiskanen, K.M., Härkönen, P., 2005. Role of mitochondria in tamoxifen-induced rapid death of MCF-7 breast cancer cells. Apoptosis. 10, 1395410.

Kruh, G.D., 2003. Introduction to resistance to anticancer agents. Oncogene 22, 7262-4.

Lacy, A., O'Kennedy, R., 2004. Studies on coumarins and coumarin-related compounds to determine their therapeutic role in the treatment of cancer. Curr. Pharm. Design. 10, 3797-3811.

Lee, J.H., Nan, A., 2012. Combination drug delivery approaches in metastatic breast cancer. J. Drug Deliv. Article ID 915375 , 1-17.

Levenson, A.S., Jordan, V.C., 1997. MCF-7: The first hormoneresponsive breast cancer cell line. Cancer Res. 57, 3071-78.

Li, F., Zhao, C., Wang, L., 2014. Molecular-targeted agents combination therapy for cancer: developments and potentials. Int. J. Cancer. 134, 1257-69.

Lippman, M., Bolan, G., Huff, K., 1976. Interactions of astrogens with human breast cancer in ling term tissue culture. Cancer Treat. Rep. 60, 1421-1429.

LoRusso, P.M., Canetta, R., Wagner, J.A., Balogh, E.P., Nass, S.J., Boerner, S.A., Hohneker, J., 2012. Accelerating cancer therapy development: the importance of combination strategies and collaboration. Summary of an Institute of Medicine Workshop. J. Clin. Cancer. Res. 18, 6101-9.

Luczkiewicz, M., Glod, D., 2003. Callus cultures of genista plants - in vitro material producing high amounts of isoflavones of phytoestrogenic activity. Plant Sci. 165, 1101-5.

Mandlekar, S., Kong, A.N., 2001. Mechanisms of tamoxifeninduced apoptosis. Apoptosis. 6, 469-77.

Mehlen, P., Puisieux, A., 2006. Metastasis: a question of life or death. Nat. Rev. Cancer 6, 449-458.

Miyoshi, Y., Ando, A., Hasegawa, S., Ishitobi, M., Taguchi, T., Tamaki, Y., Noguchi, S., 2003. High expression of steroid sulfatase mRNA predicts poor prognosis in patients with estrogen receptor-positive breast cancer. Clin. Cancer Res. 9, 2288-93.

Musa, M.A., Cooperwood, J.S., Khan, M.O.F., 2008. A review of coumarin derivatives in pharmacotherapy of breast cancer. Curr. Med. Chem. 15, 2664-79.

O’Brien, J., Wilson, I., Orton, T., Pognan, F., 2000. Investigation of the alamar blue (resazurin) fluorescent dye for the assessment of mammalian cell cytotoxicity. Eur. J. Biochem. 267, 5421-6.
Osborne, C. K., Blodt, D.H., Trent, J.M., Clark, G.M., 1982. Synchronization of human breast cancer cells with antiestrogen block and estrogen rescue. In proceeding of the $64^{\text {th }}$ annual meeting of the endocrine society, 56A, 93.

Osborne, C.K., Blodt, D.H., Clark, G.M., Trent, J.M., 1983. Effects of tamoxifen on human breast cancer cell cycle kinetics: accumulation of cells in early $\mathrm{G}_{1}$ phase. Cancer Res. 43, 3583-5.

Poma, P., Notarbartolo, M., Labbozzetta, M., Maurici, A., Carina V., Alaimo, A., Rizzi, M., Simoni, D., D’Alessandro, N., 2007. The antitumour activities of curcumin and of its isoxazole analogue are not affected by multiple gene expression changes in an MDR model of the MCF-7 breast cancer cell line: analysis of the possible molecular basis. Int. J. Mol. Med. 20, 329-35.

Purohit, A., Woo, L.W., Chander, S.K., Newman, S.P., Ireson, C., Ho, Y., Grasso, A., Leese, M.P., Potter, B.V., Reed, M.J., 2003. Steroid sulphatase inhibitors for breast cancer therapy. J. Steroid. Biochem. Mol. Biol. 86, 423-32.

Sadiu, N.E., Valente, S., Bana, E., Kirsch, G., Bagrel, D., Montenarh, M., 2012. Coumarin polysulfides inhibit cell growth and induce apoptosis in HCT116 colon cancer cells, Bioorg. Med. Chem. 20, 1584-93.

Santner, S.J., Feil, P.D., Santen, R.J., 1984. In situ estrogen production via the estrone sulfatase pathway in breast tumors: relative importance versus the aromatase pathway. J. Clin. Endocrinol. Metab. 59, 29-33.

Shou, J., Massarweh, S., Osborne, C. K., Wakeling, A.E., Ali, S., Weiss, H., Schiff, R., 2004. Mechanisms of tamoxifen resistance: increased estrogen receptor_HER2/neu cross-talk in ER/HER2-positive breast cancer. J Nation Cancer Inst. 96 (2): 926-935.

Sutherland, R.L., Taylor, I.W., Reddel, R.R., Hall, R.E., 1982. Effects of tamoxifen on the cell cycle kinetics of human mammary carcinoma cells in culture. J. Cell. Biochem. Suppl. 6, 1034A.

Suzuki, T., Nakata, T., Miki, Y., Kaneko, C., Moriya, T., Ishida, T., Akinaga, S., Hirakawa, H., Kimura, M., Sasano, H., 2003. Estrogen sulfotransferase and steroid sulfatase in human breast carcinoma. Cancer Res. 63, 2762-70.

Tanos, V., Brzezinski, A., Drize, O., Strauss, N., Peretz, T., 2002. Synergistic inhibitory effects of genistein and tamoxifen on human dyplastic and malignant epithelial breast cells in vitro. Eur. J. Obstet. Gynecol. Reprod. Biol. 102, 188-194.

Utsumi, T., Yoshimura, N., Takeuchi, S., Ando, J., Maruta, M., Maeda, K., Harada, N., 1999. Steroid sulfatase expression is an independent predictor of recurrence in human breast cancer. Cancer Res. 59, 377-81.

Woo, L.W., Howarth, N.M., Purohit, A., Hejaz, H.A., Reed, M.J., Potter, B.V., 1998. Steroidal and nonsteroidal sulfamates as potent inhibitors of steroid sulfatase. J. Med. Chem. 41, 1068-83.

Yamamoto, T., Kitawaki, J., Urabe, M., Honjo, H., Tamura, T., Noguchi, T., Okada, H., Sasaki, H., Tada, A., Yoshiteru, T., Junji, N., Makoto, Y., 1993. Estrogen productivity of endometrium and endometrial cancer tissue; influence of aromatase on proliferation of endometrial cancer cells. J. Steroid Biochem. Mol. Biol. 44, 463-8.

Yoshimura, N., Harada, N., Bukholm, I., Karesen, R., BorresenDale, A.L., Kristensen, V.N., 2004. Intratumoural mRNA expression of genes from the oestradiol metabolic pathway and clinical and histopathological parameters of breast cancer. Breast Cancer Res. 6, R46-55. 


\title{
Синергистички ефект на нови кумарински деривати и тамоксифен во блокирање на растот и предизвикување апоптоза на клетки од рак на дојка
}

\author{
Лулзиме Балажи ${ }^{1,2}$, Фаик Имери ${ }^{3}$, Александар Димовски ${ }^{1}$, Ахмед Јашари ${ }^{4}$, Емил \\ Поповски ${ }^{5}$, Пранвера Брезница-Селмани ${ }^{6}$, Божана Микхова7 ${ }^{7}$ Гералд Дрегер ${ }^{8}$, \\ Едита Алили Идризиํ, Кристина Младеновска ${ }^{1^{*}}$
}

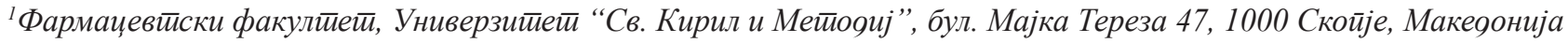 \\ ${ }^{2}$ Факулиеей за меоииински науки, Државен универзииетеи во Тетиово, ул. Паше Дерала бб, 1200, Тетиово, Макеоонија \\ ${ }^{3}$ Инстиииуй за фармаколоіија, Универзииееив во Берн, ул. Фриобул 49, СН-3010 Берн, Швајиарија

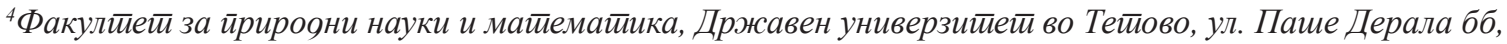 \\ 1200, Тейово, Макеоонија

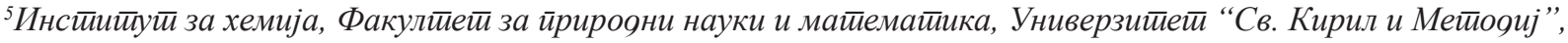 \\ РО 162, 1000 Скойје, Макеоонија

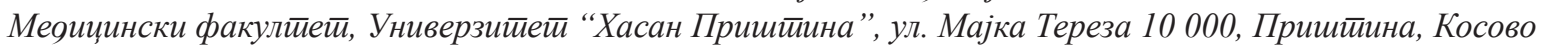

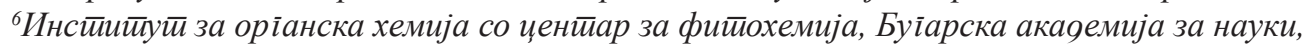 \\ Акая. Г. Бончев 9, 1113 Софија, Буіарија

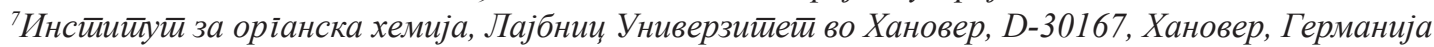

Клучни зборови: хидразинилдиен-хроман-2,4-диони, тамоксифен, рак на дојка, MCF-7 клетки, антипролиферативен ефект.

Во овој труд е испитуван потенцијалниот синергистички ефект на тамоксифен $(2 \mu \mathrm{M})$ и хидразинилдиен-хроман2,4-диони (10-100 $\mu \mathrm{M})$ со цел да се дизјанира поефективен третман за ER+ клетки на рак на дојка. Антиканцер ефектите беа оценувани во однос на пролиферацијата на MCF-7 аденокарциномните клетки на дојка со користење на МТТ и аламарСино есеите. Виталноста на клетките беше следена после третман од 48 часа, после што беа одредувани $I C_{50}$ на кумаринските деривати. Апоптотичниот ефект беше оценет со детекција на раскинувањето на поли ADP рибоза полимераза и преку намалувањето на активноста на киназа на преживување Akt. Резултатите покажаa дознозависна активност, при што процентот на инхибиција на клеточен раст после комбинираниот третман беше значајно повисок (53\% до 79\%, $10 \mu \mathrm{M}$ и $100 \mu \mathrm{M}$, соодветно) од соодветниот процент во клеточните линии третирани само со тамоксифен (29\% до 37\%) и синтетизираните кумарински деривати ( $11 \%$ до $68 \%, 10 \mu \mathrm{M}$ и $100 \mu \mathrm{M}$, соодветно). $I C_{50}$ на синтетизираните соединенија значајно се намалија во синергија со тамоксифенот ( $33 \%$ до $51 \%$ ). Кумаринскиот дериват со тиазолна структура и дополнителни метил групи на јаглеродите во позиција 5 и 4 во тиазолното јадро прикажа најголема потентност, со $I C_{50} 20 \mu \mathrm{M}$, применет сам, и $10 \mu \mathrm{M}$, во синергија со тамоксифен. Со комбинираниот третман, нивоата на фосфо- $\mathrm{Thr}^{308} \mathrm{Akt}$ беа надолно регулирани, упатувајќи на инхибиција на фосфорилацијата на тирозин киназа. Како заклучок, новите кумарински деривати ја зголемуваат активноста на тамоксифен и овој комбиниран третман може да биде соодветен за превенција на ER+ рак на дојка или за развој на сродни соединија со комбинаториска синтеза. Потребни се понатамошни студии со кои прецизно ќе се оцени типот на рецепторите одговорен за активноста и механизмот на дејство. 